The Cuban Missile Crisis 



\title{
The Cuban Missile Crisis
}

Origins, Course and Aftermath

\author{
Jonathan Colman
}

EDINBURGH

University Press 
Edinburgh University Press is one of the leading university presses in the UK. We publish academic books and journals in our selected subject areas across the humanities and social sciences, combining cuttingedge scholarship with high editorial and production values to produce academic works of lasting importance. For more information visit our website: www.edinburghuniversitypress.com

(C) Jonathan Colman, 2016

Edinburgh University Press Ltd

The Tun - Holyrood Road

12 (2f) Jackson's Entry

Edinburgh EH8 8PJ

Typeset in 11/14 Sabon by

Servis Filmsetting Ltd, Stockport, Cheshire, and printed and bound in Great Britain by

CPI Group (UK) Ltd, Croydon CR0 4YY

A CIP record for this book is available from the British Library

ISBN 9780748696284 (hardback)

ISBN 9780748696307 (paperback)

ISBN 9780748696291 (webready PDF)

ISBN 9780748696314 (epub)

The right of Jonathan Colman to be identified as author of this work has been asserted in accordance with the Copyright, Designs and Patents Act 1988 and the Copyright and Related Rights Regulations 2003 (SI No. 2498). 